BeHÇET's disease (BD) is a current systemic vasculitis of unknown aetiology. Eyes, skin, joints, the oral cavity, genital system, blood vessels, central nervous system and lung are usually involved. Defective regulation of programmed cell death (apoptosis) may play a role in the development of (BD), and the protooncogene Bcl-2 is involved in the control of apoptosis in immunocompetent cells. We therefore wished to investigate the expression of $\mathrm{Bcl}-2$ in the peripheral lymphocytes and in two inflammatory sites of patients with active BD: bronchoalveolar lavage (BAL) and cerebrospinal fluid (CSF) lymphocytes. Levels of Bcl-2 expression in the lymphocytes of patients with BD and, for comparison, in the lymphocytes of healthy controls and non-inflammatory neurological diseases (NIND), were studied by two-colour cytofluorography and RNA analysis. In BD patients, a significant proportion of $T$ cells expressed increased amounts of Bcl-2 protein, both in peripheral blood and in inflammatory sites. Mononuclear cells of patients with BD showed increased amount of Bcl-2 messenger RNA. The in vitro incubation of $T$ lymphocytes with IL-10, significantly increased the Bcl-2 expression, specifically in $T$ lymphocytes from inflammatory sites. In active BD, stimulation of HSV-1 T lymphocytes slightly increased Bcl-2 expression, not significantly different from unstimulated HSV-1 T cells. The occurrence of circulating $T$ lymphocytes with abnormally high Bcl-2 expression in peripheral circulation and in inflammatory sites may be explained in part by the increased in vivo activation levels, and by aetiopathological agent(s): our findings seem to indicate an important role in the chronic inflammation in BD.

Key words: Beh et's disease, Inflammatory sites, Bcl-2, Vasculitis

Key Indexing Term: Bcl-2 in Beh et's disease inflammatory sites

\section{Expression of Bcl-2 in inflammatory sites from patients with active Behçet's disease}

\author{
K. Hamzaoui, ${ }^{1, C A}$ A. Hamzaoui, ${ }^{2}$ L. Zakraoui $^{3}$ and \\ A. Chabbou ${ }^{2}$ \\ ${ }^{1}$ Immunohistology Laboratory, Pavillon 6, Medicine \\ University of Tunis, Tunis, Tunisia; ${ }^{2}$ Department of \\ Respiratory Diseases, Pavillon II, Ariana, Tunisia; \\ ${ }^{3}$ Department of Rheumatology, La Marsa Hospital, \\ Tunis, Tunisia \\ ${ }^{\mathrm{CA}}$ Corresponding Author \\ Medicine University Tunis, 9 Rue du Dr. Z. Essafi, 1006 \\ Tunis, Tunisia \\ Fax: (+216) 1569427
}

\section{Introduction}

Beh et's disease (BD) is a polysymptomatic, recurrent systemic vasculitis with a chronic course and an unknown aetiology. ${ }^{1}$ Several organs or systems can be involved and the resultant symptomatology and severity depend on the system affected. ${ }^{1}$ The main clinical features are: oral aphthous, genital ulcers, ocular lesions, skin lesions, arthritis, central nervous system manifestations, vasculitis ${ }^{1}$ and other less frequent findings, such as pulmonary manifestations. ${ }^{2}$ Increasing evidence indicates that immunological processes and a variety of cytokines may contribute to the pathophysiological process in $\mathrm{BD} .{ }^{3}$ We have recently reported that patients with $\mathrm{BD}$ have a dysregulation in programmed cell death. ${ }^{4,5}$
Programmed cell death (apoptosis) is important in down-modulation of immune responses after activation and proliferation of inflammatory cells. It has been suggested that dysregulated apoptosis of lymphocytes may be linked to the development of autoimmune diseases: Sjögren's syndrome, ${ }^{6}$ systemic lupus erythematosus (SLE) ${ }^{7}$ and rheumatoid arthritis (RA). ${ }^{8}$

$\mathrm{Bcl}-2$ is a proto-oncogene that regulates apoptosis of several cell types. Bcl-2 plays a role in the maintenance of the immune system, since inactivation of Bcl-2 in mice leads to the disappearance of the lymphoid system. ${ }^{9}$ Lymphocyte activation in active BD was increased, in particular in the inflammatory sites, ${ }^{1}$ so it is possible that the expression of apoptosis-regulating proteins, like $\mathrm{Bcl}-2$, is 
dysregulated in these lymphocytes. On this basis we studied Bcl-2 expression in inflammatory sites: bronchoalveolar lavage and cerebrospinal fluid.

\section{Patients and Methods}

\section{Patients}

$\mathrm{BD}$ was determined according to the criteria of the International Group for Beh et's disease. ${ }^{10}$ BD patients were receiving treatment including steroids and colchicine. Characteristics of $\mathrm{BD}$ patients are shown in Table 1. Different patient groups were used for flow cytometry and nucleic acid hybridization studies.

Bronchoalveolar lavage was isolated from 10 patients with active $\mathrm{BD}$ with lung involvement (chronic cough associated to interstitial shadows on chest X-ray or pulmonary aneurysms). ${ }^{11}$ Cerebrospinal fluid lymphocytes were isolated from five patients with neurological manifestations. ${ }^{4}$

As controls we studied peripheral blood mononuclear cells (PBMC) and cerebrospinal fluid (CSF) lymphocytes from 10 patients with non-inflammatory neurological diseases (NIND) and the bronchoalveolar lavage cells (BAL) from 12 persons undergoing routine investigations for bronchial carcinoma and whose lung X-rays were normal.

\section{Reagents}

Anti-human bcl-2 (isotype IgG) monoclonal antibodies (mAb) were purchased from Dako. AntiCD3 mAb OKT3 was from Becton-Dickinson (Mountain View, CA, USA). The negative control antibody $11 \mathrm{G} 2$ was mouse $\operatorname{IgG}_{1}$ mAb to chicken Bu-1b alloantigen. ${ }^{12}$ Fluorescein isothiocyanate (FITC)-conjugated anti-human $\mathrm{CD} 3$, and mouse IgG were purchased from Becton-Dickinson. Unspecific mouse IgG (I-5381) was purchased from Sigma (St Louis, MO, USA) and streptavidin - phycoerythrin (PE) (7100-09) from Southern Biotechnology Associates (Birmingham, AL, USA). Purified human recombinant IL-2, IL10 , and neutralizing anti-IL-10 mAb were from Genzyme Diagnotics.

Table 1. Clinical features of patients with Behçet's disease

\begin{tabular}{|c|c|c|c|}
\hline Patient & Age/sex & Disease activity & Symptoms at the time of sampling \\
\hline 1 & $40 / \mathrm{M}$ & Active & Or ulcer - Gen ulcer - Uveitis - Pulm. \\
\hline 2 & $45 / \mathrm{M}$ & Remission & No symptom \\
\hline 3 & $36 / F$ & Active & Or ulcer - Gen ulcer - Uveitis - EN \\
\hline 4 & $37 / F$ & Active & Or ulcer - Gen ulcer - Uveitis \\
\hline 5 & 28/M & Active & Or ulcer - Gen ulcer \\
\hline 6 & $57 / \mathrm{M}$ & Active & Or ulcer - Gen ulcer - Pulm \\
\hline 7 & $26 / \mathrm{M}$ & Active & Or ulcer - Gen ulcer - Uveitis - Pulm \\
\hline 8 & $45 / \mathrm{M}$ & Active & Or ulcer - Gen ulcer - Arthritis \\
\hline 9 & $47 / \mathrm{M}$ & Active & Or ulcer - Gen ulcer - Uveitis - CNS - Arthritis \\
\hline 10 & $63 / \mathrm{M}$ & Partial remission & Or ulcer \\
\hline 11 & $29 / F$ & Remission & No symptom \\
\hline 12 & $32 / \mathrm{M}$ & Active & Or ulcer - Gen ulcer - Uveitis - Arthritis \\
\hline 13 & $35 / \mathrm{M}$ & Active & Or ulcer - Gen ulcer - CNS \\
\hline 14 & $56 / \mathrm{M}$ & Active & Or ulcer - Gen ulcer - Uveitis \\
\hline 15 & $58 / \mathrm{M}$ & Active & Or ulcer - Gen ulcer - Arthritis \\
\hline 16 & 33/M & Active & Or ulcer - Gen ulcer - Uveitis \\
\hline 17 & $34 / \mathrm{M}$ & Active & Or ulcer - Gen ulcer - Uveitis - Pulm \\
\hline 18 & $21 / \mathrm{M}$ & Active & Or ulcer - Gen ulcer - EN \\
\hline 19 & $18 / \mathrm{M}$ & Active & Or ulcer - Gen ulcer - Arthritis \\
\hline 20 & $40 / \mathrm{M}$ & Active & Or ulcer - Gen ulcer - Uveitis \\
\hline 21 & $49 / F$ & Active & Or ulcer - Gen ulcer \\
\hline 22 & $42 / \mathrm{M}$ & Active & Or ulcer - Gen ulcer - Uveitis - EN \\
\hline 23 & $35 / \mathrm{M}$ & Partial remission & Or ulcer - Gen ulcer - Arthritis \\
\hline 24 & $27 / \mathrm{M}$ & Active & Or ulcer - Gen ulcer - Uveitis - Arthritis \\
\hline 25 & 29/M & Active & Or ulcer - Gen ulcer - Uveitis - Pulm \\
\hline 26 & $28 / \mathrm{M}$ & Active & Or ulcer - Gen ulcer - Uveitis - CNS \\
\hline 27 & $17 / \mathrm{M}$ & Active & Gen ulcer - Uveitis - Arthritis \\
\hline 28 & $36 / F$ & Active & Or ulcer - Gen ulcer - EN \\
\hline 29 & $34 / \mathrm{M}$ & Active & Or ulcer - Gen ulcer - Uveitis - Pulm \\
\hline 30 & $52 / \mathrm{M}$ & Active & Or ulcer - Gen ulcer - Uveitis - Pulm \\
\hline 31 & $46 / \mathrm{M}$ & Active & Or ulcer - Gen ulcer - Uveitis - CNS \\
\hline 32 & $43 / \mathrm{M}$ & Active & Or ulcer - Gen ulcer - Uveitis - CNS \\
\hline 33 & $27 / \mathrm{M}$ & Active & Or ulcer - Gen ulcer - Uveitis - Pulm \\
\hline 34 & $36 / \mathrm{M}$ & Active & Or ulcer - Gen ulcer - Uveitis - Arthritis - Pulm \\
\hline 35 & $38 / \mathrm{M}$ & Active & Or ulcer - Uveitis - Arthritis - Pulm \\
\hline
\end{tabular}

Or ulcer, oral aphthous ulceration; Gen ulcer, genital ulceration; EN, erythema nodosum; CNS, central nervous system involvement; Pulm, pulmonary manifestation, artery aneurysm. 


\section{Cell preparations and cultures}

Peripheral blood, cerebrospinal and bronchoalveolar lymphocytes were isolated by Ficoll-Hypaque (Pharmacia, Uppsala, Sweden) density-gradient centrifugation and washed twice with PBS at $+4^{\circ} \mathrm{C}$. Lymphocytes were cultured at $10^{6}$ cells $/ \mathrm{ml}$ per well in Iscove's modified Dulbecco's medium (Gibco) supplemented with $10 \%$ fetal calf serum and $50 \mu \mathrm{g} / \mathrm{ml}$ gentamycin. Cells were cultured in 24-well plates (Costar, Cambridge, MA) at $37^{\circ} \mathrm{C}$ in a $5 \% \mathrm{CO}_{2}$ incubator (Jouan). IL$2(50 \mathrm{U} / \mathrm{ml})$, IL-10 $(100 \mathrm{U} / \mathrm{ml})$ or anti-IL-10 mAbs $(2 \mu \mathrm{g} / \mathrm{ml})$ were added at the onset of the cultures. After a culture period of 7 days, cells were harvested and washed twice with $1 \%$ bovine serum albumin (BSA). Cells were stained and analysed using flow cytometry as described below.

\section{Generation of HSV-1 stimulated T cells}

Four millilitres of cells at $2 \times 10^{6}$ cells/ml were cultured in tissue culture flasks, in the presence of UV-inactivated $\mathrm{HSV}-1$, in an incubator with $5 \% \mathrm{CO}_{2}$ and $95 \%$ air for 6 days, as previously reported. ${ }^{13}$ On the day of testing, the cells were washed and the number of viable cells was determined by trypan blue exclusion. The cells were resuspended in RPMI 1640 medium supplemented with $25 \mathrm{mM}$ Hepes buffer and $10 \%$ heat-inactivated FCS.

\section{Immunofluorescence staining and flow cytometric analysis}

A total of $10^{6}$ cells were incubated for 30 min with anti-Bcl-2 monoclonal antibody (mAbs), followed by incubations with biotinylated anti-mouse IgG and streptavidin-PE in 1\% BSA, $0.3 \%$ saponin, followed by two washes in $1 \%$ BSA, $0.1 \%$ saponin. For two-colour analysis, cells were then incubated with unspecific mouse IgG for $15 \mathrm{~min}$ and stained with FITC-conjugated $\mathrm{mAbs}$ for $30 \mathrm{~min}$ without saponin. The negative controls included the replacement of anti-Bcl$2 \mathrm{mAb}$ with a negative control antibody (11G2) of the same isotype and the staining of cells without saponin permeabilization. Cells with light scatter characteristics of lymphocytes were gated and analysed using LYSYS II software from a FACScan (Becton-Dickinson) flow cytometer.

\section{RNA isolation and nucleic acid hybridization}

Total RNA was extracted from PBMC and inflammatory sites cells (BAL and CSF mononuclear cells) as described by Chirgwin et al. ${ }^{14}$ Briefly, cells were homogenized in $4 \mathrm{M}$ guanidium isothiocyanate and RNAs were purified with ultracentrifugation through caesium chloride cushions. To verify the integrity of RNA preparations, a small amount of RNA from each sample was electrophoresed in $1 \%$ agarose/formaldehyde and stained with ethidium bromide. Five micrograms of total RNA were dot blotted onto a nylon membrane (Hybond-N+; Amersham International). The filter was hybridized and washed under stringent conditions according to the manufacturer's protocol. Human Bcl-2 cDNA was excised from pN2-H-BCL2 vector. ${ }^{15}$ It recognizes the appropriate size $8.5-\mathrm{kb}$ RNA. The glyceraldehyde 3-phosphate dehydrogenase cDNA clone pHGAPDH was used as a reference probe. ${ }^{16}$ The probes were labelled with $\left[{ }^{32} \mathrm{P}\right] \mathrm{dATP}$ (PB.10204; Amersham), using a random priming DNA labelling kit (70200; USB, Cleveland, OH, USA), to obtain specific activities of $1-2 \times 10^{9} \mathrm{dpm} / \mu \mathrm{g}$. After labelling, probes were run through Sephadex G50 spin columns. The autoradiograms from the sequential hybridization of a dot blot filter with $\mathrm{Bcl}-2$ and GAPDH probes were analysed with a scanning densitometer, and the densitometric readings were normalized to the amount of RNA in each sample.

\section{Results}

\section{Bcl-2 immunofluorescence}

To quantitate the expression of Bcl-2 protein in the T lymphocytes from patients with active $\mathrm{BD}$, we studied

Table 2. Bcl-2 expression as mean fluorescence intensity (MFI) in peripheral blood T lymphocytes (PBMC), bronchoalveolar lavage $T$ lymphocytes (BAL) and cerebrospinal fluid lymphocytes (CSF) from controls and active BD with pulmonary manifestations and neurological involvement

\begin{tabular}{|c|c|c|c|c|c|}
\hline \multirow[t]{2}{*}{ Sample } & \multirow{2}{*}{$\begin{array}{l}\text { No. of } \\
\text { patients }\end{array}$} & \multirow{2}{*}{$\begin{array}{l}\text { Mean fluorescence } \\
\text { intensity } \pm \text { S.D. }\end{array}$} & \multicolumn{3}{|c|}{ Bcl-2-positive lymphocytes \pm SD $(\%)$} \\
\hline & & & Medium & $+\mathrm{IL}-2$ & $+\mathrm{IL}-10$ \\
\hline Control PBL & 25 & $56 \pm 17$ & $72 \pm 6$ & $84 \pm 22 *$ & $96 \pm 12 *$ \\
\hline Active BD-PBL & 35 & $92 \pm 8 t$ & $87 \pm 8$ & $90 \pm 15$ & $87 \pm 8$ \\
\hline Control BAL & 12 & $28 \pm 14$ & $52 \pm 6$ & $80 \pm 3^{*}$ & $74 \pm 10^{*}$ \\
\hline Active BD-BAL & 10 & $46 \pm 10 \dagger$ & $78 \pm 3$ & $74 \pm 10$ & $90 \pm 7^{*}$ \\
\hline NIND-CSF & 10 & $32 \pm 14$ & $53 \pm 7$ & $72 \pm 6^{*}$ & $70 \pm 3^{*}$ \\
\hline Active BD-CSF & 05 & $63 \pm 6 t$ & $74 \pm 5^{*}$ & $94 \pm 4^{*}$ & $96 \pm 15^{*}$ \\
\hline
\end{tabular}



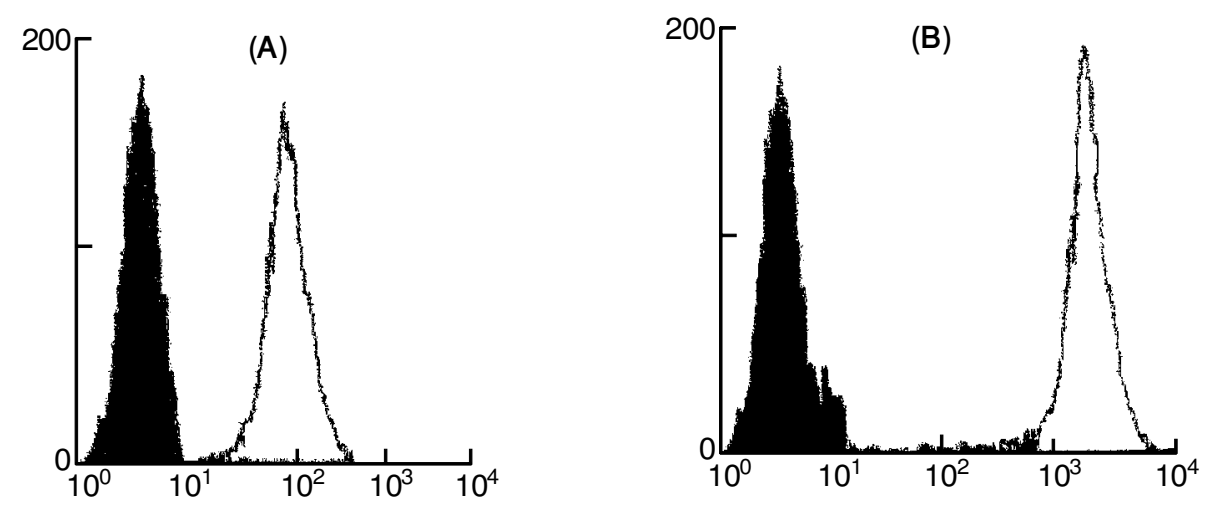

FIG. 1. Immunofluorescence histogram showing Bcl-2 expression lymphocytes of bronchoalveolar lavage from controls (A), and patients with active Behçet's disease (BD) with pulmonary manifestations (B). The black histograms indicate fluorescence intensity of control antibodies. Data are representative of 10 normal controls and eight active BD. Bcl-2 was expressed in CD3+ BAL-T lymphocytes at a higher intensity.

Bcl-2 expression in 35 peripheral blood mononuclear cells (PBMC), 10 BAL and five CSF from patients with active BD, using flow cytometry. As shown in Table 2, Bcl-2 expression in PBL from active BD was high compared to healthy controls. In every lymphocyte sample, from CSF and BAL of active BD $>80 \%$ were Bcl-2 positive when compared to CSF from NIND and BAL from healthy controls. In addition, the MFI of Bcl2-positive cells in the BAL and CSF from active BD were clearly increased when compared to BAL of healthy controls and CSF from patients with NIND (Figs 1 and 2).

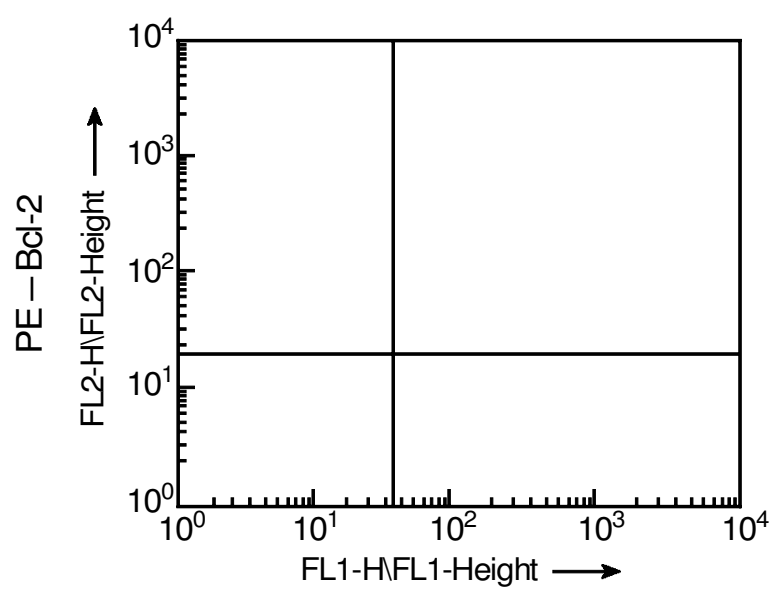

FITC-CD3

FIG. 2. Results of double staining experiments on the lymphocytes of representative bronchoalveolar lavage from patients with active Behçet's disease with pulmonary manifestations. Freshly isolated lymphocytes were stained with FITC-conjugated anti-human CD3 monoclonal antibody. Following this step cells were permeabilized and then stained with biotinylated polyclonal rabbit IgG anti-human $\mathrm{Bcl}-2$, as described in Patients and Methods. As control for the expression of $\mathrm{Bcl}-2$, cells were incubated with biotinylated rabbit $\lg \mathrm{G}$ and then with $\mathrm{PE}$-conjugated streptavidin.

\section{Effect of IL-2 and IL-10 on Bcl-2 expression}

The Bcl-2 expression analysed by flow cytometry was studied in cultured T cells incubated with IL-2 and IL10. The addition of IL-2 did not change significantly the percentage of $\mathrm{Bcl}-2$ expression on peripheral $\mathrm{T}$ cells and $\mathrm{T}$ lymphocytes from inflammatory sites: bronchoalveolar lavage and cerebrospinal fluid lymphocytes. However, IL-10 increased significantly the Bcl-2 expression (Table 2), specifically in $\mathrm{T}$ lymphocytes from inflammatory sites. The increased $\mathrm{Bcl}-2$ expression was abrogated when anti-IL10 was added.

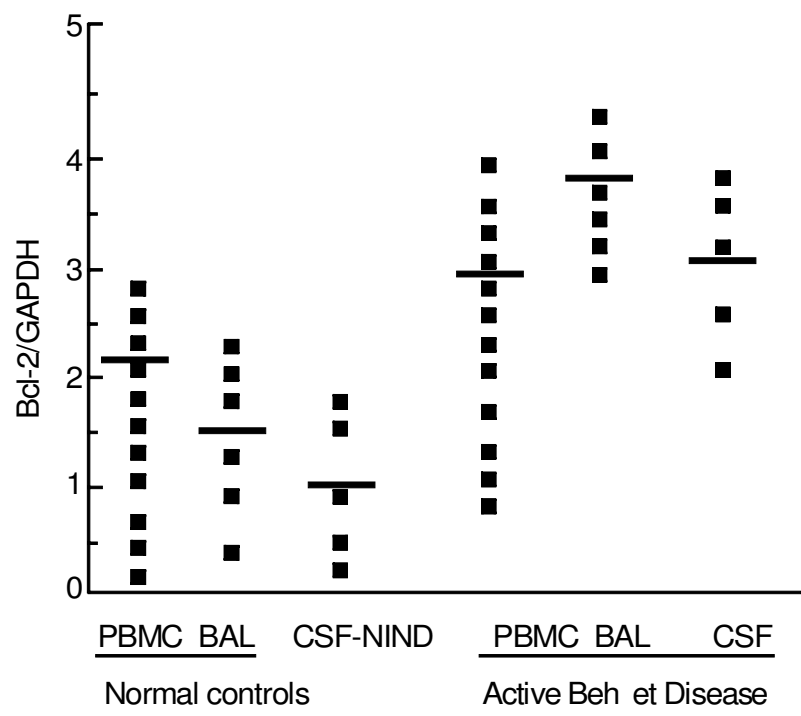

FIG. 3. The expression of Bcl-2 mRNA in peripheral blood, bronchoalveolar lavage (BAL) and cerebrospinal fluid (CSF), cells from patients with active Behçet's disease (BD). Seven micrograms of total RNA were blotted onto nylon membrane and hybridized sequentially with $\mathrm{Bcl}-2$ and GAPDH probes. The dots represent the ratios of densitometric reading of Bcl2 and GAPDH expression. Each dot represents one patient. Mean values are indicated by a line. 
Table 3. Bcl-2 expression as mean fluorescence intensity (MFI) in peripheral blood T lymphocytes (PBL) after HSV-1 stimulation, in healthy controls $(n=10)$, patients with NIND $(n=7)$ and patients with active BD $(n=12)$. Lymphocytes were cultured in the presence of UV-inactivated HSV-1 in an incubator with $5 \% \mathrm{CO}_{2}$ for 6 days. On the day of testing cells were washed and resuspended in RPMI 1640 medium

\begin{tabular}{lcc}
\hline Sample & \multicolumn{2}{c}{$\begin{array}{c}\text { Mean fluorescence } \\
\text { intensity } \pm \text { S.D. }\end{array}$} \\
\cline { 2 - 3 } & $\begin{array}{c}\text { Before HSV-1 } \\
\text { stimulation }\end{array}$ & $\begin{array}{c}\text { After HSV-1 } \\
\text { stimulation }\end{array}$ \\
\hline Healthy Controls & $53 \pm 12$ & $84 \pm 6^{*}$ \\
NIND & $42 \pm 16$ & $82 \pm 10^{*}$ \\
Active BD & $82 \pm 9.5$ & $97 \pm 22$ \\
\hline
\end{tabular}

${ }^{*} P<0.001$ compared to non-HSV-1-stimulated cells.

\section{Bcl-2 mRNA expression}

The increased expression of Bcl-2 in active $\mathrm{BD}$ at the inflammatory sites could be demonstrated at the RNA level. Bcl-2 mRNA expression was studied in active BD in 12 PBMC, six BAL and five CSF samples. As a control, we used 10 PBMC and six BAL from healthy controls and five CSF from patients with NIND. The expression of Bcl-2 mRNA in PBMC from active BD was increased compared to healthy controls. BAL and CSF from active $\mathrm{BD}$ exhibited an increase in the expression of Bcl-2 mRNA compared to BAL from controls and CSF from patients with NIND (Fig. 3).

\section{Bcl-2 expression after HSV-1 stimulation}

The expression of Bcl-2 proto-oncogene was quantified in peripheral blood T cells after HSV-1 stimulation (Table 3) in active BD, compared to NIND and healthy controls. In healthy controls and patients with NIND, Bcl-2 expression exhibited a drastic increase after HSV-1 stimulation $(P<0.001)$. In active $\mathrm{BD}, \mathrm{Bcl}-2$ expression increased slightly, but was not significantly different from unstimulated HSV-1 T cells.

\section{Discussion}

Our findings indicate that $\mathrm{Bcl}-2$ is overexpressed in patients with active BD, both in PBMC and inflammatory sites: BAL and CSF. This conclusion is based on results obtained using flow cytometry and nucleic acid hybridization. An increased expression of Bcl-2 has been previously demonstrated in active $\mathrm{BD},{ }^{4}$ and in SLE. ${ }^{17}$ The mRNA level expression of apoptosisrelated gene product did not differ between SLE cells and normal donor cells. Expression of Fas/APO-1 protein was increased in freshly isolated SLE $T$ lymphocytes compared with normal donor T lymphocytes, whereas Bcl-2 protein was up-regulated after a 3-day culture period. ${ }^{18}$ Dysregulation of the apoptosis system in RA is controversial. ${ }^{19}$ Increased $\mathrm{Bcl}-2$ expression, and in general programmed cell death dysregulation, seemed to lead to autoimmune disease and/or viral processes.

Some autoimmune mechanisms are involved in the etiopathogenesis of $\mathrm{BD},{ }^{1}$ although there are disagreements as to whether BD should be classified as an autoimmune disease. ${ }^{20}$ The main immunological finding in autoimmune disease is $\mathrm{T}$ cell hypofunction. ${ }^{21} \mathrm{BD}$ is essentially characterized by $\mathrm{T}$ cell hyperactivity. ${ }^{22}$ Taking into account flow cytometry results and nucleic acid hybridization, we can conclude that there is a certain similarity between BD and SLE in the apoptosis defect, characterized by increased $\mathrm{Bcl}-2$ expression.

A possible explanation for the increased $\mathrm{Bcl}-2$ expression in the peripheral blood and inflammatory sites in $\mathrm{BD}$, was the increased production of $\mathrm{IL}-2,{ }^{23}$ because IL-2 has been shown to increase $\mathrm{Bcl}-2$ expression in active T cells. ${ }^{24}$ On the other hand, IL-10 has demonstrated to modulate the expression of Bcl-2 in leukaemia cells. ${ }^{25}$ IL-10 is highly produced by PBMC3 and plasma ${ }^{26}$ from patients with BD. Therefore, we studied the roles of IL-2 and IL-10 in the regulation of Bcl-2 expression by culturing lymphocytes with exogenous IL-2, IL-10 or neutralizing anti-IL-10 mAb. Our in vitro data suggest that IL-2 cytokine is not responsible for the increased expression of $\mathrm{Bcl}-2$ in $\mathrm{BD}$ inflammatory sites and peripheral blood lymphocytes. However, IL-10 is able to increase in vitro expression of Bcl-2, in peripheral blood lymphocytes and in inflammatory lymphocytes. This increase was abrogated when lymphocytes were incubated with anti-IL10.

In patients with SLE, a prominent role for IL-10 in the induction of apoptosis was observed, ${ }^{27}$ as neutralizing anti-IL-10 mAb markedly reduced cell death in active SLE patients by $50 \%{ }^{27}$ Using Western blotting, it has been demonstrated that exposure of IL-10 to T cells, enhanced the expression of $\mathrm{Bcl}-2$, inhibiting $\mathrm{T}$ cell apoptosis, and this is associated with a normal proliferative function. ${ }^{28}$

In patients suffering from viral infection, the induction of apoptosis may result in virus clearance. In contrast the inhibition of apoptosis may result in virus cell transformation and viral persistence. Epidemiological data favour an infectious cause, and $\mathrm{T}$ cell hypersensitivity for $\mathrm{BD}$ : Streptococcus sanguis, ${ }^{29}$ parvovirus $B 19,{ }^{30}$ and bacterial superantigens, ${ }^{31}$ have been associated with $\mathrm{BD}$. Antibodies to herpes simplex virus 1 (HSV-1), were found to be increased in patients with active $\mathrm{BD} .{ }^{32},{ }^{33}$ In a limited number of patients with BD, a HSV-1-DNA fragment was found in peripheral blood lymphocytes by polymerase chain reaction (PCR). HSV DNA was found in biopsy samples taken from genital ulcers by applying PCR, and the 289-bp protein of HSV DNA was also detected in these lesions, but not in controls. ${ }^{33},{ }^{34}$ 
The in vivo antigenic stimulation in active $\mathrm{BD}$ is responsible for : (i) the activation of $\mathrm{T}$ lymphocytes which is characterized by a divergent cytokine production profile of mixed Th1/Th2 cell types; ${ }^{35}$ (ii) the switch of naïve $\mathrm{T}$ cells to memory lymphocytes; ${ }^{22}$ and (iii) the alteration of the inflammatory sites, with destruction of the host tissues. All these factors might account for the mechanisms of cell death observed in our patients, which were characterized by increased soluble CD95/APO-1, ${ }^{4}$ and increased expression of Bcl2 in the peripheral circulation and in the inflammatory sites. Our results with regard to the lack of equilibrium in apoptosis mechanisms in $\mathrm{BD}$, was corroborated with the insufficient expression of Fas on activated $\mathrm{CD}^{+}$cells in $\mathrm{BD} .{ }^{36} \mathrm{CD} 4^{+} \mathrm{T}$ cells from patients with active $\mathrm{BD}$, were characterized to mediate specific cytotoxicity against HSV-1. ${ }^{13}$

Our data confirmed that HSV-1 increased Bcl-2 expression in active $\mathrm{BD}$, undergoing apoptosis in response to a variety of different agents. The question is, whether Bcl-2 is able to interfere with Fas-induced apoptotic cell death? Data indicate that $\mathrm{Bcl}-2$ is capable of inhibiting both the perforin/granzyme B- and Fasinduced apoptotic cell death. ${ }^{37}$ Confirmation should be established in the BD context.

Based on these data, we conclude that the specific programmed cell death in BD might be explained, at least in part, by the increased in vivo activated levels of lymphocytes in peripheral blood and in inflammatory sites. The increased $\mathrm{Bcl}-2$ protein expression in active BD are non-specific for the disease, and may be explained at least in part by the increased in vivo activation levels, or autoimmune vasculitides combined with in vivo induction by aetiopathological agent(s). These findings $s^{4,5,36}$ seem to play an important role in the chronic inflammation in BD.

\section{References}

1. Kaklamani VG, Vaiopoulos G, Kaklamani PG. Beh et's disease. Semin Arthr Rheum 1998: 27: 197-217.

2. Hamzaoui K, Hamzaoui A, Hentati F, Kahan A, Ayed Kh, Chabbou A Phenotype and functional profile of $\mathrm{T}$ cells expressing receptor from patients with active Beh et's disease. J Rbeumatol 1994: 21: 2301-2306.

3. Raziuddin S, Al-Dalaan A, Bahabri S, Siraj AK, Al-Sedairy S. Divergent cytokine production profile in Beh et's disease. Altered Th1/Th2 cell cytokine pattern. J Rbeumatol 1998: 25: 329-333

4. Hamzaoui A, Hamzaoui K, Kooli Ch, Chabbou A. High levels of bcl-2 protein in the T lymphocytes of patients with Beh et's disease. Clin Exp Rbeumatol 1996: 14: 106-108.

5. Hamzaoui K, Hamzaoui A, Zakraoui L, Chabbou A. Levels of soluble Fas/ APO-1 in patients with Beh et's disease. Mediators Inflamm 1998: 7: 111-114.

6. Ichikawa Y, Arimori K, Yoshida M, Hoshina Y, Uchiyama M, Shimizu H, Moriuchi J, Takaya M. Abnormal expression of apoptosis-regulated antigens, Fas and bcl-2, on circulating T-lymphocyte subsets in primary Sjögren syndrome. Clin Exp Rbeumatol 1995: 13: 307-313.

7. Aringer M, Wintersberger W, Steiner CW, Kierner H, Presteri E, Jaeger U, Smolen JS, Graninger W B. High levels of bcl-2 protein in circulating T lymphocytes, but not B lymphocytes of patients with systemic lupus erythematosus. Artbr Rbeum 1994: 37: 1423-1430.

8. Isomäki P, Söderström K-O, Punnonen J, Roivainen A, Luukkainen R, Merilahti-Palo R, Nikkari S, Lassila O, Toivanen P. Expression of bcl-2 in Rheumatoid arthritis. Br J Rbeumatol 1996: 35: 611-619.

9. Nakayama K, Neghishi I. Disappearance of the lymphoïd system in bcl-2 homozygous mutant chimeric mice. Science 1993: 261: 1584-1588.
10. International study group for Beh et's disease : Criteria for diagnosis of Beh et's disease. Lancet 1990: 335: 1078-1080.

11. Hamzaoui A, Hamzaoui K, Chabbou A, Ayed Kh. Circulating intercellular adhesion molecules in blood and bronchoalveolar lavage in Beh et's disease. Mediators Inflamm 1995: 4: 355-358.

12. Veromaa T, Vainio O, Eerola E, Toivanen P. Monoclonal antibodies against chiken Bu-1a and Bu-1b alloantigens. Hybridoma 1988: 7: 41-48.

13. Hamzaoui K., Kahan A., Ayed Kh., Hamza M. Cytotoxic T cells against herpes simplex virus in Beh et's disease. Clin Exp Immunol 1990: 81: 390-395.

14. Chirgwin JM, Przybyla AE, MacDonald RJ, Rutter WJ. Isolation of biologically active ribonucleic acid from sources enriched in ribonuclease. Biochemistry 1979: 18: 5294-5300.

15. Nunez G, Seto M, Seremetis S. Growth- and tumor-promoting effects of deregulated BCL2 in human B-lymphoblastoïd cells. Proc Natl Acad Sci USA 1989: 86: 4589-4593.

16. Akbar AN, Borthwick N, Salmon M. The significance of low bcl-2 expression by CD45RO T cells in normal individuals and patients with acute viral infections. The role of apoptosis in T cell memory. J Exp Med 1993: 178: 427-438.

17. Isomäki P, Söderström KO, Punnonen $\mathbf{J}$, Roivainen A, Luukkainen $\mathbf{R}$ Merilahti-Paolo R, Nikkari S, Lassila O, Toivanen P. BrJ Rbeumatol 1996: 35: 611-619.

18. Lorenz MH, Grunke M, Hieronymus T, Herrmann M, KuhnelA, Manger B Kalden JR. In vitro apotosis and expression of apoptosis-related molecules in lymphocytes from patients with systemic lupus erythematosus and other autoimmune diseases. Arthr Rbeum 1997: 40: 306-317.

19. Hang L, Theophilopoulos AN, Dixon FJ. A spontaneous rheumatoid arthritis-like disease in MRL/1 mice. J Exp Med 1982: 155: 1690-1695.

20. Yazici $H$. The place of Beh et's syndrome among the autoimmune diseases. Int Rev Immunol 1997: 14: 1-10.

21. Barnes CG. Beh et's syndrome. Trop Rev 1991: 18.

22. Kahan A, Hamzaoui K, Ayed Kh, Hamza M. Abnormalities of T lymphocyte subsets in Beh et's disease demonstrated with anti-CD45RA and antiCD29 monoclonal antibodies. J Rheumatol 1992: 19: 742-745.

23. Hamzaoui K, Ayed Kh. High affinity interleukin-2 receptors on peripheral blood lymphocytes are decreased during active Beh et's disease. Clin Exp Rbeumatol 1990: 8: 100-101.

24. Deng G, Podack ER. Suppression of apoptosis in a cytotoxic T-cell line by interleukin-2-mediated gene transcription and deregulated expression of the proto-oncogene bcl-2. Proc Natl Acad Sci USA 1993: 90: 2189-2193.

25. Fluckiger AC, Durand I, Banchereau J. Interleukin 10 induces apoptotic cell death of B-chronic lymphocytic leukemia cells. J Exp Med 1994: 179: 91-99.

26. Turan B, Gallati H, Erdi H, Gurler A, Michel BA, Villiger PM. Systemic levels of the T cell regulatory cytokines IL-10 and IL-12 in Beh et's disease; soluble TNFR-75 as a biological marker of disease activity. $J$ Rbeumatol 1997: 24: 128-132.

27. Georgescu L, Vakkalouka RK, Elkou KB, Ceow MK. Interleukin-10 promotes activation-induced cell death of SLE lymphocytes mediated by Fas Ligand. J Clin Invest 1997: 100: 2622-2633.

28. Cohen SBA, Crawley JB, Kahan MC, Feldmann M, Foxwell BM. Interleukin-10 rescues $\mathrm{T}$ cells from apoptotic cell death: association with an upregulation of bcl-2. Immunology 1997: 92: 1-5.

29. Mizushima Y. Beh et's disease. Curr Opin Rbeumatol 1991: 3: 32-35.

30. Kiraz S, Ertenli I, Benekli M, Calguneri M. Parvovirus B19 infection in Beh et's disease. Clin Exp Rheumatol 1996: 14: 71-73.

31. Hiroata $S$, Hashimoto $T$. Abnormal $T$ cell responses to bacterial superantigens in Beh et's disease. Clin Exp Immunol 1998: 112: 317-324.

32. Hamzaoui K, Ayed Kh, Hamza M, Touraine JL. Natural killer cell activity, interferon-gamma and antibodies to herpes simplex virus in patients with Beh et's disease. Clin Exp Immunol 1990: 79: 28-34.

33. Bang D, Cho YH, Coi HJ, Lee S, Sohn S, Lee ES. Detection of herpes simplex virus DNA by polymerase chain reaction in genital ulcer of patients with Beh et's disease. In: VIIth International Conference on Beh et's disease (Abstract A19). Rev Rbum (English edition) 1996: 63: 532.

34. Lee ES, Lee S, Bang D, Sohn S. Herpes simplex virus detection by polymerase chain reaction in intestinal ulcer of patient with Beh et's disease. In: VIIth International Conference on Beh et's disease (Abstract A18). Rev Rhum (English edition) 1996: 63: 531

35. Raziuddin S, Al-Dalaan A, Bahabri S, Siraj A K, Al-Sedairy S. Divergent cytokine production profile in Beh et's disease. Altered Th1/Th2 cell cytokine pattern. J Rheumatol 1998: 25: 329-333.

36. Nakamura S, Sugita M, Matoba H, Tanaka S, Isoda F, Ohno S. Insufficient expression of Fas antigen on helper T cells in Beh et's disease. $\mathrm{BrJ}$ Ophtalmol 1996: 80: 174-176.

37. Schrter M, Lowin B, Tschapp J. Regulation of Fas (Apo-1/CD95) and perforin mediated lytic pathways of primary cytotoxic $\mathrm{T}$ lymphocytes by the protooncogene bcl-2. Eur J Immunol 1995: 25: 3509-3519. 


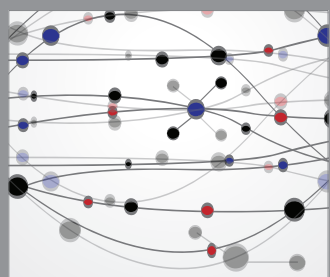

The Scientific World Journal
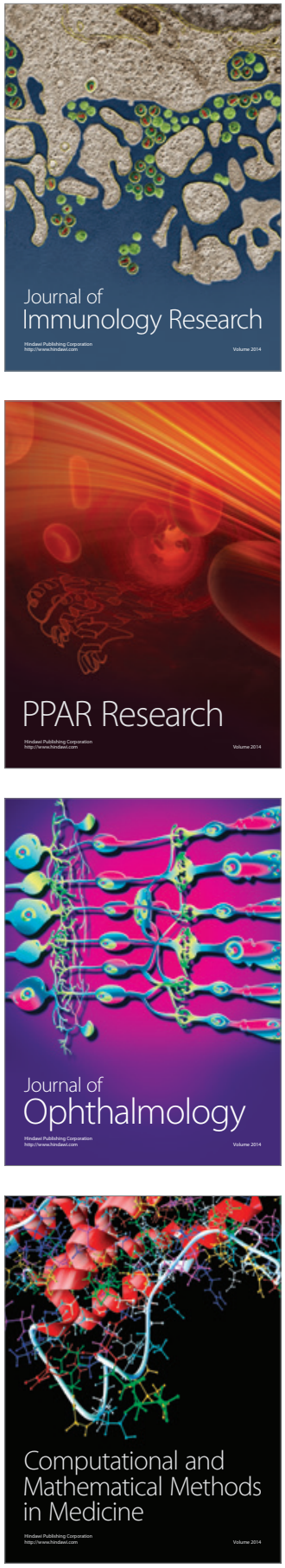

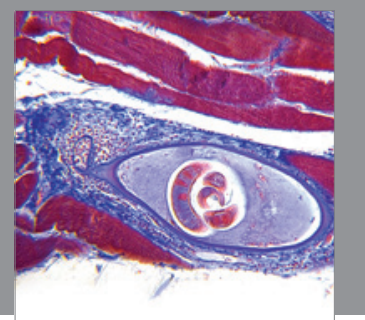

Gastroenterology

Research and Practice
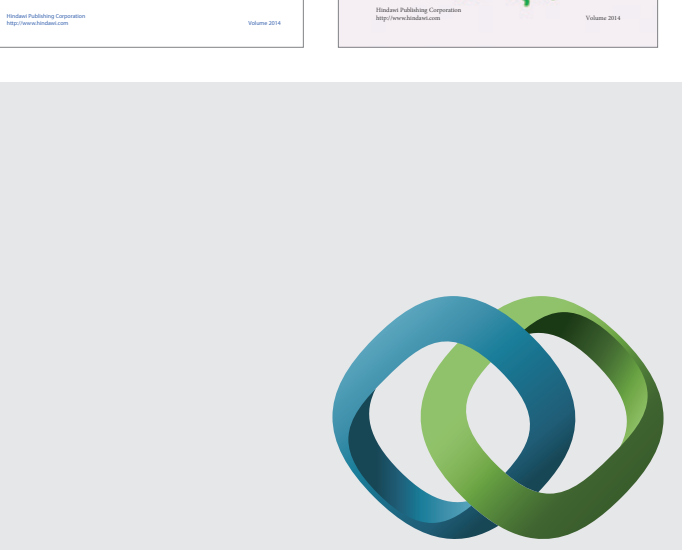

\section{Hindawi}

Submit your manuscripts at

http://www.hindawi.com
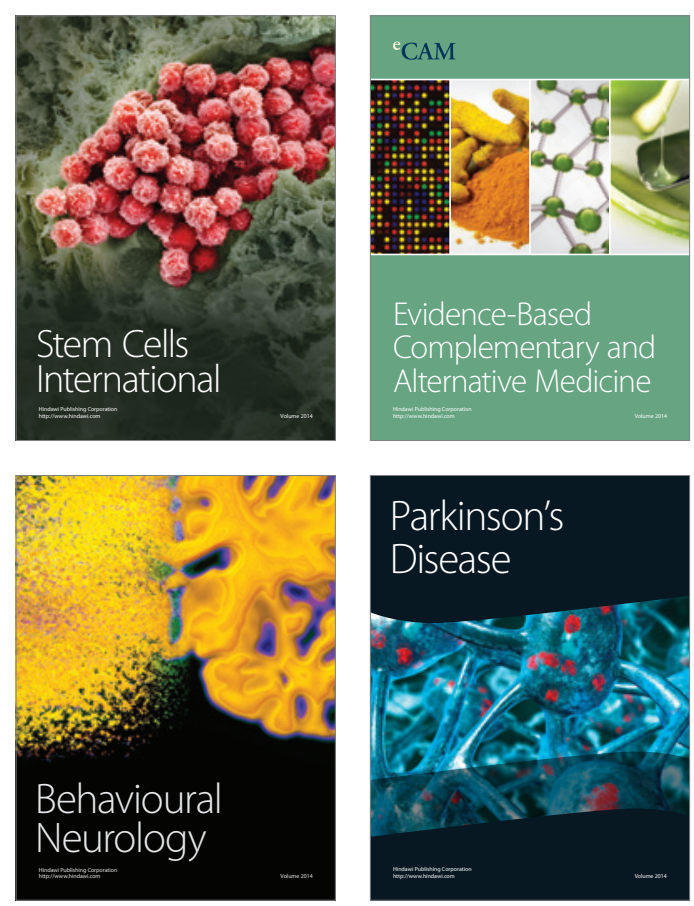

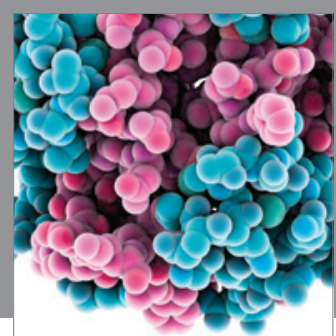

Journal of
Diabetes Research

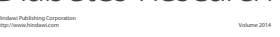

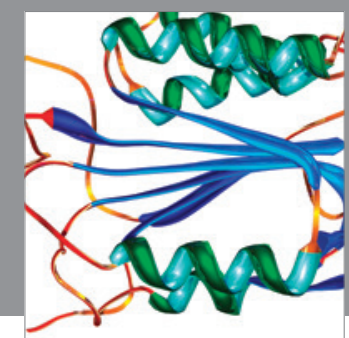

Disease Markers
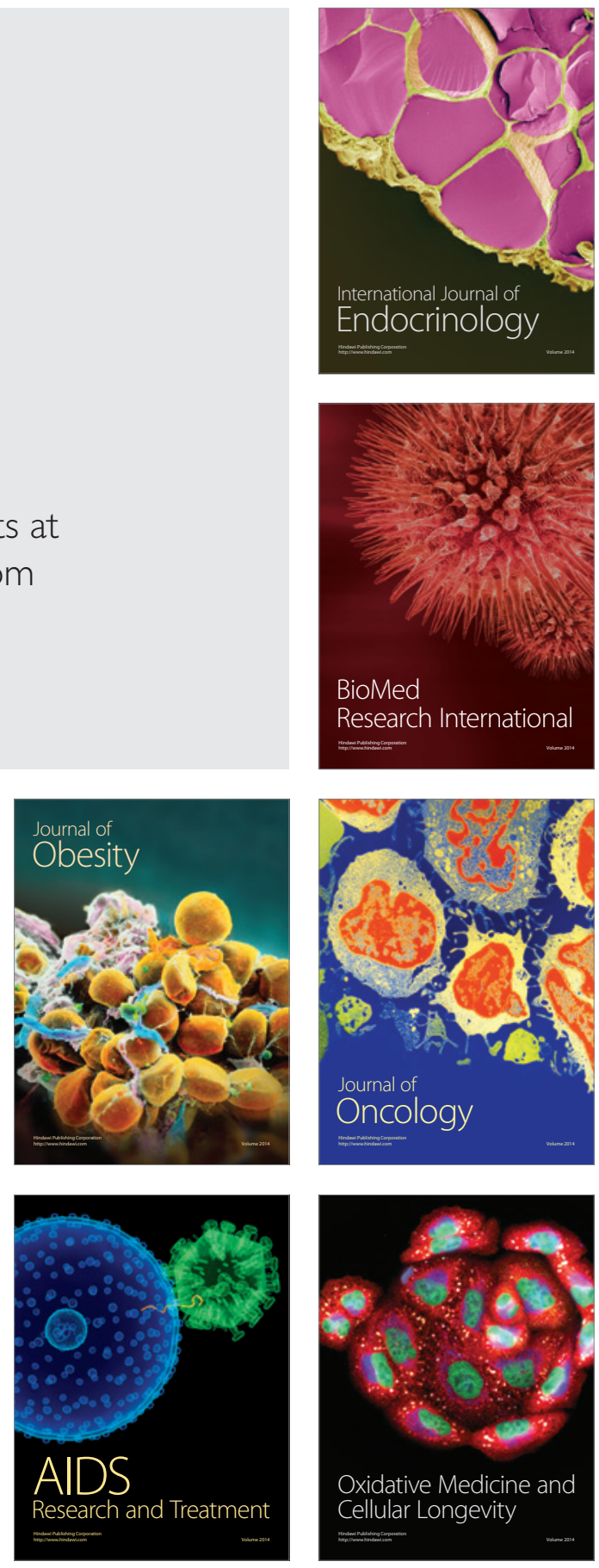